(С) М.А. Насекин, А.В. Буганов

\title{
ВОЕННАЯ ПОВСЕДНЕВНОСТЬ ГРАЖДАНСКОГО НАСЕЛЕНИЯ СТАЛИНГРАДА В 1942-1943 ГГ. (ПО ДНЕВНИКАМ АННЫ АРАЦКИХ И СЕРАФИМЫ ВОРОНИНОЙ)
}

\begin{abstract}
Подсчитайте, живые,
Сколько сроку назад

Был на фронте впервые

Назван вдруг Сталинград.

Твардовский. Василий Теркин

Статья написана на материалах дневников жительниц Сталинграда Анны Арацких и Серафимы Ворониной, которые они вели в период знаменитой битвы 1942-1943 г2., под непрестанными бомбежками, когда Сталинград превратился из прифронтового города в фронтовой. Жители Сталинграда оказались заложниками воюющей местности. В архивных документах отражены военная повседневность, эмочииональное, нравственное состояние мирных жителей, тяжести их выжсивания на грани человеческих возможностей. Авторы описывают условия быта в руинах, сложности с обеспечением населения питанием. Продовольственные магазины и лавки были практически уничтожены, водопроводные коммуникачии разрушены, регулярного подвоза воды не было. В таких условиях притуплялось чувство восприимчивости, человек привыкал ко всему: к голоду, холоду и даже смерти. На страницах дневников авторы не только рассказывали о событиях, в гуще которых они оказались, но и делились самым сокровенным, «изливали» душу, выражали свои заботы и переживания, помощь и поддержку другим.

Сталинградская битва обернулась трагедией для мирного населения. Как и в бою, людям было необходимо находить правильные решения в критических ситуачиях. Из-за постоянного перемещения линии фронта им также приходилось менять свое место жительства, обустраиваться на новом месте. Повседневная жизнь гражданского населения протекала буквально на передовой и определялась экстремальностью состояния общества, страны, народа в крупномасштабной войне. Речь ила не просто о проявлении патриотизма, но о коллективной жертвенности и героизме во имя общего дела. В дни обороны города это становилась нормой. В дневниках через личностное восприятие, типичное для тысяч и тысяч простых людей, проявлялся глубокий трагизм дней оборонь Сталинграда.
\end{abstract}

Насекин Максим Анатольевич - ведущий методист, ФГБУК «Государственный историко-мемориальный музей-заповедник “Сталинградская битва ”» (400053 Волгоград ул. им. Маршала В.И. Чуйкова, 47). Эл. почта: nasekin.maks@mail.ru

Буганов Александр Викторович - д.и.н., заведующий отделом русского народа, главный научный сотрудник, Институт этнологии и антропологии РАН (Москва, Ленинский просп., 32а). Эл. почта: buganov@rambler.ru ORCID: http://orcid.org/0000-0001-7590-2162 
Ключевые слова: Сталинград, человек, война, повседневность, страх, смерть, жизнь, память

Ссылка при цитировании: Насекин М.А., Буганов А.В. Военная повседневность гражданского населения Сталинграда в 1942-1943 гг. (по дневникам Анны Арацких и Серафимы Ворониной) // Вестник антропологии, 2021. № 2. С. 26-34.

Сталинградская битва длилась с 17 июля 1942 г. по второе февраля 1943 г. Шесть с половиной месяцев в бескрайних донских и приволжских степях не утихали тяжелые кровопролитные бои. На отдельных этапах битвы на Волге в сражении участвовало, с обеих сторон, до двух миллионов человек. О Сталинградской битве написано много мемуаров, публицистики, поэзии, прозы. Есть отличные книги, например, повести В. Некрасова «В окопах Сталинграда» и К. Симонова «Дни и ночи», роман Ю. Бондарева «Горячий снег». Сохранились фотодокументы и дневниковые записи. В 2014 г. на их основе С. Садовский создал документальный фильм о детях Сталинграда, кому тогда было 12, а кому лишь годик. Теперь они последние свидетели Сталинградской трагедии.

В статье источниками для изучения военной повседневности гражданского населения Сталинграда выступают произведения эпистолярного жанра - дневники Серафимы Ворониной и Анны Арацких, написанные авторами в период обороны Сталинграда. Дневники велись, когда в городе начались уличные бои, и Сталинград превратился из прифронтового города в фронтовой. На страницах дневников авторы описывают последствия варварских бомбардировок города, условия жизни в руинах, при ведении боевых действий, сложные условия со снабжением продовольствием. Эти дневники-хроники сохранились в фондах музея-заповедника «Сталинградская битва».

Автор первого дневника Анна Михайловна Арацких родилась в Сталинграде в 1920 г., в семье вместе с ней было 9 детей. Образование получила среднее специальное по профессии бухгалтер. В 1940 г. работала в Сталинградском военно-авиационном училище летчиков. В октябре 1942 года месяце вступила вместе с матерью в армию. Анна Арацких, начиная с 5-го класса имела привычку вести дневник. Первый дневник с девичьими довоенными воспоминаниями она брала даже в окопы и во время бомбежек и обстрелов делала записи. В одном из окопов дневник был утерян. Второй дневник Анна стала вести с конца августа 1942 г., когда у неё вновь появились тетрадка и карандаш. Дневник в марте 2002 года передала в музей её сестра Лидия Михайловна Арацких.

Второй дневник принадлежит Серафиме Федоровне Ворониной. Родилась она в 1905 г. в Царицыне (Сталинград-Волгоград) в семье рабочего. Серафима Федоровна свою трудовую деятельность начала в 17 лет, учительствовала на селе в начальной школе. Закончила вечернее педагогическое училище. Работая учительницей литературы в школе, поступила в Сталинградский педагогический институт, закончила литературный факультет в 1941 г. В дни войны ушла работать на завод «Красный Октябрь». При бомбежке Сталинграда в августе 1942 г. был тяжело ранен её 72-летний отец. После начала уличных боев в Сталинграде могла эвакуироваться, но имея на своих руках престарелую мать и раненого отца, осталась в городе. В семье было 7 человек: отец, мать, сестра Женя и брат, сестра Ирина с мужем. В живых остались только Ирина с дочерью Татьяной и Женя с сыном Игорем. Погибла в ноябре 1942 г. Дневник Серафимы Ворониной был найден в феврале 1943 г. в руинах Сталинграда между заводами 
«Красный Октябрь» и «Баррикады», недалеко от Волги. В музей его прислал участник Сталинградской битвы Я.И. Бридихин из города Харцынзск Донецкой области.

Сталинградская битва обернулась трагедией не только для военных, но и для населения города. Как и в бою, мирным гражданам было необходимо находить правильное решение в критических ситуациях. Повседневная жизнь определялась экстремальностью состояния общества, страны, народа в крупномасштабной войне.

Тяжелейший след в воспоминаниях и судьбе сталинградцев оставили постоянные бомбардировки города. Первый массированный налет вражеской авиации на город был совершен в ночь с 22 на 23 апреля 1942 г. и продолжался 3 часа 23 минуты. В налете учувствовало 50 вражеских самолетов. Только на Тракторозаводский район противник в ту ночь сбросил 1500 зажигательных и 15 фугасных бомб (Самсонов 1989: 78). С 23 по 29 августа проходили «ковровые» бомбардировки города, и за этот период в Сталинграде погибло по разным данным от 42000 до 71000 мирных жителей и 142000 получили ранения (Павлова: 2005: 202).

В дневнике А. Арацких 30 августа 1942 г. была сделана запись: «23 августа 1942 г. День был солнечным, теплым, тихим. Папа принес две пригоршни муки, она была какая-то серая и сильно пахла дымом. Отец тихо сказал, мать накорми детей, ведь они такие голодные. Мама как чувствовала, положила два кирпича, на них железку и стала разводить муку водой. Масса получилась темно серая, из нее мама испекла пышку». Пышку ждали все, но она досталась Лиде [ей было 6 лет, самой маленькой из детей - прим. М.Н. и А.Б.] Как только Лида съела пышку, небо стало темным. Началась «бомбежка, какой не было. Вокруг стоял свист, все стало черным, крики детей, взрослых, вой собак, пожары, взрывы, все грохотало и горело. Я же сидела и переживала, где же та самая кастрюлька с мукой, из которой мама сделала пышку.

Утром мы увидели, что все сгорело, во дворе было две воронки, сплошной пепел, руины, мама в истерике стала кричать. А я все искала ту кастрюлю и ту «печку», где мама пекла пышку, но от нее не осталось и следа. Вокруг трупы, разбитые дома, сгоревшие трамваи, вывернутые рельсы. Где-то недалеко рвались нефтяные баки, и нефть рекой текла в Волгу, горела сама река» (Арацких: 24988. Л. 1).

С началом регулярных бомбежек жители города прятались в окопах-щелях. В них было безопаснее, чем в подвалах домов. При попадании бомбы в дом было практически невозможно самостоятельно выбраться из руин. Щели же находились относительно на открытой местности, и их маскировали. От прямого попадания бомбы они не спасали, но в них было спокойнее. «Ближе к воздуху», - как говорили жители. Рыли их неширокими, глубокими и зигзагообразными. При обстрелах с пикировки можно было увильнуть от пуль и осколков. Прятались и в норах, которые отрывали в склонах оврагов. В свое примитивное жильё брали только самые необходимые вещи. В городе по состоянию на 15 апреля имелось 66300 погонных метров открытых и закрытых щелей для укрытия населения, построенных силами МПВО и гражданского населения. (Самсонов 1982: 79). Сталинградцы днями, а то и месяцами не выходили из своего жилища, находились заложниками окопной жизни. Человек испытывал физические неудобства, постоянно находился в угнетенном эмоциональном состоянии, испытывал напряжение, чувство страха, подавленность, постоянное ожидание смерти. Своими эмоциями безусловно хотелось поделиться, но с кем? Записи в дневниках давали эмоциональную разгрузку. Вот что писала А. Арацких: «Уже целая неделя с того момента, как сидим в окопе с 23 августа. От Сталинграда 
остались обгорелые камни, да жертвы ни в чём неповинных людей. Сегодня опять целый день сидим в окопе, и не знаю, когда этому придёт конец. Сколько слёз пролито за эти 13 дней. Сегодня пятница, а в воскресенье две недели, бомбить продолжают, хотя бомбить уже нечего. Сегодня бомбили всю ночь, и перед рассветом разбросали зажигательные бомбы на нашу улицу. Мы были в огненном плену. Но бог спас нас, и слава богу. Ой господи, неужели мы не вынесем всего того страшного, кругом стреляют, на улицах баррикады. Кошмар, наверное, ещё впереди. Сейчас пишу на ступеньке за крышей окопа, на камушке. Мой милый дневник, когда же придет конец всему страданию. Теперь я вспоминаю новогодний сон - большой белый крест, вот оно моё терпение. Эх, как ни хочется умирать, не видя жизни. Если буду жива, никогда не забуду 1942 год и этот окоп»»». (Араџких: 24988. Л. 2).

Положение гражданского населения усугубилось после того, как 13 сентября 1942 г. после авиационной и артиллерийской подготовки противник начал штурм города. К постоянному чувству страха и ожидания смерти прибавилась боязнь попасть в плен к немцам. Положение с продовольственным обеспечением ухудшилось. Из дневника С. Ворониной: «С 13 сентября с воскресенья идут сильные бои. Со стороны немцев летят минометы, с нашей стороны бухают «Катюши». С самого воскресенья пять дней бомбили ... были небольшие перерывы. По ночам затишье, но спим тревожно, самолеты летают всё ночь, но не бомбят. Латает самолет-разведчик, вешает на парашютах фонари и освещает всё пространство. Делается так светло, как днем. Разведчик все высматривает, а днем начинается бомбежка. Мы с мамой и знакомыми живем в балке, Костя вырыл нам убежище, щель. Пять дней не вылезаем из этого убежища. Отец находится в щели дома. С ним находится Сергей Иванович, знакомый. Из всех дней бомбежки самым страшным был вчера 16 сентября. Какой был вчера ужас, какой ужас. Бомбили целый день с 8 утра до 8 вечера. И всё бомбили наш район, т.к. недалеко от нашей балки находится рабочий склад, а в нём стоят войска, машины. Вокруг находятся индивидуальные домики с садами, тут же находится и наш дом. Вчера бомба попала в сад к Кузовым, убило хозяина Илью Ивановича... красноармейца. Илья Иванович бежал в щель, по дороге его и убило. Жена его сильно, Екатерина Ивановна плакала. Вчера его и схоронили в саду, в воронке упавшей бомбы, Боже мой, какой ужас! Какой был ужас. Останемся ли мы живы, если останемся, то постареем лет на 20» (ЛФ Ворониной: Л.2).

В сентябре 1942 г. город превратился в сплошную линию фронта. На улицах появились военная техника, артиллерия и тяжелые орудия. Обстрелы и бомбардировки немцы проводили с присущими им педантичностью. Серафима Воронина писала: «Каждое утро с 8 часов начинается стрельба и бомбежка. Вот и сейчас стали бухать. т.к. летят немецкие самолеты. 14 сентября информбюро сообщило о сдаче Новороссийска, как-то там наши сватья, живы ли. Ну, кончаю писать, начинается стрельба. Закутываемся в подушки, одеяла и лежим ни живы, ни мертвы. Дни теплые, солнечные» (ЛФ Ворониной: Л. 3).

На страницах своих дневников авторы не только описывали события, в гуще которых они оказались, но и делились самым сокровенным, своими страхами и болью. В тяжелых фронтовых буднях почти не было времени с кем-то задушевно поговорить, «излить» душу. Наверное, в этих обстоятельствах письменное слово, как никакое другое, помогало провести эмоциональную разгрузку. В семье Анны Арацких 27 сентября 1942 г. произошла трагедия, от пули снайпера погиб отец семьи Михаил 
Арацких. Долго переживала дочь смерть близкого человека, не сразу смогла сделать запись в своем дневнике. Появилась она лишь 14 ноября: «Вот потерян навсегда мой самый дорогой человек - отец! Снова и снова нахлынули воспоминания о Папе, каждый день, каждый час, каждую минуту. С Папой было хорошо, с ним мы все были вместе в родном гнезде. Куда теперь нас разбросает судьба? Так и сидели мы в окопе все вместе, пока не погиб наш дорогой человек-Папочка! Его убил немец-снайпер.

Помню как полтора месяца тому назад, вечер 26 сентября, было очень тихо, светила полная луна, ни ветерка, ни тучки, ни одного выстрела. Пришёл папа и сказал: «А ну, вылезайте все из окопа, и подышите воздухом», а сам взял на руки свою любимую Лиду, так как она меньше всех, ей 6 лет. Мы все расселись около него. В тот вечер Папочка был почему-то такой задумчивый, казалось, что глаза его смотрели в одну точку, на Волгу, в них было видно даже отражение «золотой» лунной дорожки. Папа говорил, что все мы уже большие (кроме Лиды), все ему станем помогать, что скоро погоним немцев, и мы снова построим себе дом, выстроим его еще больше и еще лучше. Вспоминали, где кто побывал, папа впервые улыбнулся за вечер и сказал, что я больше всех остальных побывала в других городах. Так приятно было сидеть рядом с Папой, с ним как то не так страшна была войны. Затем он проводил нас спать в окоп, а сам что-то ещё очень долго делал по устройству нашего окопа.

А 27 сентября рано утром Папа разбудил нас, на улице было тихо, ярко светило сентябрьское солнце, вода блестела и казалось, застыла на месте, как залитое кем- то зеркало, казалось все кончено, нет больше войны.

Папа как всегда по утрам приготавливался идти развести костер, что бы сварить манную кашу. В это время прибежали два Вити и впервые нарушили эту мертвую тишину, перекинувшись двумя фразами... А Папа в это время открыл крышку окопа и крикнул соседу: «Шура, выходи, вы жив...» На этом недосказанном слове оборвалась его жизнь. Раздался выстрел, скорее какой-то щелчок, и Папа стал медленно оседать на стенки окопа. Все это произошло в какой-то миг... я все слышала сквозь утреннюю дрему, а когда раздался выстрел-щелчок, я сразу открыла глаза, и первое что я увидела - оседающего беспомощного и всего в крови Папу. Мама стояла в этот момент завороженная и смотрела на него, неспособная сдвинуться с места. Я побежала к нему первая, так как сидела крайняя в окопе рядом с Мамой. Но было уже поздно, Папа был мертв, хотя пульс и сердце ещё бились, а кровь лилась ключом из его правого виска, я пробовала пальцем остановить кровь, но мой палец легко прошел в отверстие, и кровь лилась, лилась, лилась...! Мы кричали все.. Витя стоял молча с широко открытыми глазами и смотрел на Папу, по щекам его текли слезы. В это же время его волосы чесали пули, видимо того же снайпера, летали мимо ушей, плеча, а он всё стоял будто не замечая ничего вокруг себя. Я кричала ему «беги Витя, беги отсюда». Началась такая ужасная стрельба, но мы её уже не слышали, крыша нашего окопа опустилась, оставив нам небольшое отверстие, и мы погрузились в свое неутешное горе.

Где был Витя? Что с ним? мы не знали, так как он остался там наверху, а мы в окопе. Потом мы увидели, точнее, услышали голос Пачика, он смотрел на Папу, такими же удивленными глазами, что и Витя, только спросил: «Что разве убили дядю Мишу?», а сам ползал вокруг окопа, как кошка и приговаривал: «Туже перевяжите его». Затем все смолкло, и мы увидели опустившуюся к нам в окоп руку, с пальцев которой лилась кровь к нам в окоп, были видны ноги обутые в такие же ботинки, что у Вити, и мы поняли что на крыше лежит убитый Виктор, горе наше удвоилось и мы потеряли рас- 
судок. Так мы сидели с мертвым Папой, без еды и воды два дня. Много погибло людей в тот день, самым первыми погиб наш Папа. Погибли наши соседи Вера и Евдокия Павловна. Здесь же рядом с окопом было много трупов убитых бойцов.

Лишь поздно вечером второго дня, с тихим плачем подошла к окопу тетя Маруся, и мы услышали голос нашего Виктора. Не верилось, Виктор был жив, а погиб, оказалось Пачик, верный друг Виктора, ведь он пришел для того, чтобы разделить с нами наше горе и погиб сам, видимо, от рук того же снайпера.

Тетя Маруся плакала так тихо, что её плач никто не слыхал, ведь он у неё был единственный и любимый сын. Затем они помогли нам вытащить из окопа труп Папы. На следующий день, как стемнело, мы обернули труп Папа в простыню и схоронили в подвале у Подлесновых» (Арацүких: 24989. Л. 3-4).

В сталинградских дневниках авторы часто описывают сложности с обеспечением продовольствием гражданского населения, которые, конечно, во время войны были повсеместно. Сталинград, в отличие от Ленинграда, не находился в изоляции от страны, но в городе шли бои, продовольственные магазины и лавки были практически уничтожены. Жители города ходили на руины, собирали горящее зерно с элеватора, муку с обгорелых мукомольных предприятий. Очень редко можно было отыскать в остатках продовольственных магазинах что-то съестное. Основные водопроводные коммуникации города были разрушены в августе 1942 г., регулярного подвоза воды не было. Воду можно было взять в Волге, на родниках, в пожарных ёмкостях промышленных предприятий. Каждый поход за продуктами или водой был связан с риском для жизни. В сентябре 1942 г. С. Воронина сделала запись: «Встала сегодня поздно, в 9 часов, день был пасмурный, было тихо. Собралась идти за водой. Мама не пускала, но я всё-таки пошла. Вода в кранах на Баррикадах. Набрала воды, вдруг зашумели самолеты, побежала бегом с ведрами. Забежала в барак растрёпанный, в нём было две женщины, девочка и два красноармейца. Началась бомбежка, я прижалась в коридоре барака к углу, девочка легла на пол в коридоре, женщина побежала по бараку, красноармейцы легли на пол. Началась бомбежка, штукатурка сыплется, грохот. Что я пережила, описать не возможно. Когда немного затихло, я взяла ведра с водой и побежала домой» (ЛФ Ворониной: Л.4.).

Сколько эмоциональных потрясений испытывал человек по пути к живительной влаге. Смерть родных и близких, друзей и соседей - и это нужно было пережить. Притуплялось чувство восприимчивости, человек привыкал ко всему: к голоду, холоду и даже смерти. Вместе с тем, как отмечал К. Симонов: «Война не есть сплошная опасность, ожидание смерти и мысли о ней. Если бы это было так, то ни один человек не выдержал бы тяжести ее... даже месяц. Война есть совокупность смертельной опасности, постоянной возможности быть убитым, случайности и всех особенностей и деталей повседневного быта, которые всегда присутствуют в нашей жизни... Человек на фронте занят бесконечным количеством дел, о которых ему постоянно нужно думать и из-за которых он часто совершенно не успевает думать о своей безопасности. Именно поэтому чувство страха притупляется на фронте, а вовсе не потому, что люди вдруг становятся бесстрашными» (Симонов 2005: 85).

В ноябре 1942 г. А. Арацких сделала запись в своём дневнике: «Дойдя до берега, я увидела трупы Веры и её матери, их трупы даже никто не присыпал землёй. Шла самая последняя, голова кружилась, сил не было, ноги распухли и ужасно болели. Меня подняли бойцы, но я снова падала и не стояла на ногах, словно пьяная, помню, 
не благодарила их и была в каком-то забвении. Нервы были напряжены до предела. Помню, когда мы все же добрались до берега, сразу же бросились к воде, во рту все пересохло и хотелось пить. Пили жадно, много, здесь же на берегу было много убитых бойцов» (Арацких: 24988. Л.8).

Судя по дневниковым записям, сталинградцы в условиях постоянных эмоциональных потрясений, сумели не просто адаптироваться к ним, но сохранить сопричастность, теплые и дружественные отношения с окружающими. Забота и переживания, помощь и поддержка - все это нашло отражение на страницах дневников. С. Воронина писала: «Дом весь растрепан, соседские дома стоят. Вошла в дом, всё в нём расщеплено, вышла на улицу, оказалось, что бомба упала у окон дома, в то место, где посажена сирень. Собрали кое-какие доски с улицы во дворе. Дедушка сосед помог забить забор. Вечером пришел Сергей Иванович и забил нам окна, поднял забор со стороны стадиона, перетаскал кое-какой лес во дворе. Мама меня всё уговаривает идти в балку, к знакомым, но я никуда не хочу идти, будь что будет. Фронт находится в нескольких местах в 4 км от города, в некоторых в 7 км. Вчера проходил молоденький красноармеец, попросил пить, он и говорил, что фронт находится в разных местах» (ЛФ Ворониной: Л. 7).

Из-за постоянного перемещения линии фронта, жителям также приходилось менять свое место жительства, искать новые щели, окопы, полуразрушенные блиндажи. Обустраиваться на новом месте в военных условиях было сложно, но война есть война. Нахождение гражданского населения буквально на передовой - вот так можно охарактеризовать повседневную жизнь сталинградцев. С. Воронина пишет: «Сегодня военный утром ходил по всем дворам и выбирал место для установления пушки, вот беда-то. Оставаться и в своей щели становится невозможно, ну что делать? Мама говорит, что надо ехать за Волгу и пробираться вглубь степи. У нас живут одни знакомые, зовут с собой за Волгу. Не знаю, что и делать. Пойду сегодня схожу на Волгу, на переправу и узнаю, как обстоит дело, сажают ли с тележкой. Если бы с тележкой посадили, то кое-что можно было увезти с собой. Отец ещё больной, как он ещё дойдет. Говорила с ним утром насчёт поездки за Волгу, говорит, что как-нибудь с палочкой дойдет. Не знаю, что и делать, как быть. Положение очень напряженное. Вот уже сидим в окопе 34 дня, больше месяца, конца не видно» (ЛФ Ворониной: Л. 8).

Жители Сталинграда стали заложниками воюющего города, но велась, насколько возможно, эвакуация гражданского населения. Правда, проходила она в условиях, когда город был практически стерт с лица земли, а противник рассматривал в бинокль правый берег Волги. Да и многие горожане отказывались уезжать. Для большинства населения эвакуироваться - означало бросить всё и уйти в никуда.

Вот как эвакуировалась семья Арацких. Утром на берегу переправы в районе Красного Октября было много носилок с тяжелоранеными. Стояло три переполненных пароходика, но когда «начальник посмотрел на Маму с Лидой, на нас всех, сердце его видимо не вытерпело, он громко сказал раненым: «Потеснимся, товарищи, и возьмем эту семью».

Из-за тесноты на пароходике стоять можно было только на одной ноге. Сразу после отплытия появились немецкие самолеты, посыпалось множество бомб. Пароходик качало так, что каждую секунду он мог перевернуться, но благодаря мужеству капитана люди добрались до берега. Последовала команда не скапливаться и бежать в лес.

«Легко сказать бежать, но как? Сил бежать не было, ноги совсем не слушались... Всем хотелось добраться до полосы спасения-леса, все спешили туда, те, кто мог идти, 
а идти могли не многие, большинство были тяжело ранены, повсюду стояли носилки с ранеными, геройски проявляли себя санитары и персонал пароходика. Самолеты летели очень низко и стреляли по нам, хотя было видно, что идут раненые. Когда добрались до леса, а он был в нескольких метрах от берега, силы почти оставили нас...

Потом сели в машину и поехали... «а куда? Не все ли равно. И опять бомбежка, мы то садились в машину, то слезали с неё, бежали и прятались или просто падали плашмя, раскинувшись на дороге. Потом варили чай в лесу, отдыхали, кажется по настоящему - лежа, ведь такой возможности, сидя в окопе не имели. А утром снова сели на машину и поехали дальше от пылающего, сожженного города, от Папы...»

Так на попутных машинах Арацкие добрались до Камышина. Шли холодные со снегом дожди, одеться было не во что, все осталось в городе, закопанное возле разбомбленного дома. «Переночевать нас никто не пускал, да и что мы могли дать за ночлег? Семья наша была большая, мама и около неё пять человек. Так мы дрожали и мокли под дождем, под открытым небом, голову и ту некуда было спрятать. Помню, нашли мы на окраине Камышина погребок для коз и залезли туда. О! это было просто блаженство. Но счастье было не долгим, вышла хозяйка, накричала на нас и выгнала. И пошли мы с тяжелым камнем в сердце, не зная, куда же нам пойти, надвигалась ночь, было так холодно, лил мокрый дождь со снегом. Лида плакала, шли по дороге до тех пор, пока не пришли к регулировке. Около регулировочной будки было много народа, остановились мы, в надежде подъехать куда-нибудь на машине. Сидели долго, промокли до нитки, а что было делать? А потом подошла машина, из неё вышел какой-то начальник, подошел к нам и сказал «Вы кто и куда едете?» Мы сказали, что ехать нам некуда и ехать куда нам сами не знаем, может где-нибудь колхоз устроился» (Араџких: 24989. Л. 9-11).

По-разному сложилась судьба авторов сталинградских дневников. Мать Анны Арацких, Ксения Степановна после смерти мужа 11 октября 1942 г., имея при себе 5-х детей, добровольно вступила в армию, в 10-ю резервную, а позже 5-ю ударную армию, вместе с детьми в полевой прачечный отряд № 374 (Арацุких: 24989. Л. 7). Серафима Воронина погибла при очередной бомбежке в ноябре 1942 г.

В истории Сталинградской победы было немало примеров выживания за гранью человеческих возможностей. Речь шла не просто о проявлении патриотизма, но о коллективной жертвенности и героизме во имя общего дела. В дни обороны города это становилась нормой. Источники, которыми для нас стали созданные авторами в экстремальных условиях дневники, несут в себе глубокий трагизм дней обороны Сталинграда через личностное восприятие тысяч и тысяч простых людей. Авторы дневниковых записей создали в дни войны ценные письменные источники о повседневности гражданского населения Сталинграда, в которой на первое место выходит человек Болышой войны.

\section{Источники и материалы}

ЛФ Ворониной - Личный фонд Ворониной Серафимы Федоровны. Федеральное государственное бюджетное учреждение культуры «Государственный историко-мемориальный музей-заповедник «Сталинградская битва» (МЗСБ). Книга поступлений основного фонда (КП), 12232.

Араџких - Федеральное государственное бюджетное учреждение культуры «Государственный историко-мемориальный музей-заповедник «Сталинградская битва». Научно-вспомогательный фонд (МЗСБ НВФ) 24988-89. П. 175.

Симонов 2005 - Симонов К.М. Разные дни войны. Дневник писателя 1942-1945 годы. М.: Грифон М, 2005. С. 654. 


\title{
Научная литература
}

Павлова Т.А. Засекреченная трагедия: Гражданское население в Сталинградской битве. Волгоград.: Перемена, 2005. 594 с.

Самсонов А.М. Сталинградская битва. 4-е изд., испр. и доп. М.: Наука, 1989. 624 с.

Nasekin, Maxim A., and Alexander V. Buganov

\section{Military Everyday Life of the Civilian Population of Stalingrad in 1942-1943 (according to the diaries of Anna Aratskikh and Serafima Voronina)}

\author{
DOI: $10.33876 / 2311-0546 / 2021-54-2 / 26-34$
}

The article is based on the diaries of Anna Aratskikh and Serafima Voronina, residents of Stalingrad during the notorious battle of 1942-1943. The diaries were written under constant bombardment, when Stalingrad turned from a city near the front-line into a front-line city. The population of Stalingrad became hostage to the fighting city. The archival documents reflect the military everyday life, the emotional, moral state of the people, and survival on the verge of human capabilities. The authors describe the living conditions in the ruins, the difficulties in the food supply. Grocery stores and shops were devastated, water pipelines were destroyed, and there was no regular water supply. Human sensitivity was dropping away, one got used to everything: to hunger, cold and even death. On the pages of the diaries, the authors not only described the events they witnessed, but also shared the most intimate feelings, expressed their concerns and experiences, support to others. The battle of Stalingrad turned into a tragedy for the civilian population of the city. As in combat, they needed to look for the right solutions in critical situations. Due to the constant movement of the front line, residents also had to move and settle down in new places. The daily life of the civilian population took place literally in the trenches and was determined by the extreme situation of the large-scale war, which affected the society, the country, the people. It was not just patriotism, but a collective sacrifice and heroism in the name of a common cause. In the days of the city's defense, this became the new norm. The diaries describe the deep tragedy of the days of the defense of Stalingrad through the personal perception of thousands and thousands of ordinary people.

Keywords: Stalingrad, humans, war, everyday life, fear, death, life, memory

For Citation: Nasekin, M.A., and A.V. Buganov. 2021. Military everyday life of the civilian population of Stalingrad in 1942-1943 (according to the diaries of Anna Aratskikh and Serafima Voronina). Herald of Anthropology (Vestnik Antropologii) 2: 26-34.

\section{Author Info:}

Nasekin, Maxim A. - leading methodologist, State Historical and Memorial Museum-Reserve "Battle of Stalingrad" (Volgograd, Russia). E-mail: nasekin.maks@mail.ru

Buganov, Alexander V. - Dr. (Hist.), Head of the Department of the Russian People, Chief Research Fellow, Institute of Ethnology and Anthropology Russian Academy of Sciences (Moscow, Russia). E-mail: buganov@rambler.ru ORCID: http://orcid.org/0000-0001-7590-2162

\section{References}

Pavlova, T.A. 2005. Zasekrechennaia tragediia: Grazhdanskoe naselenie v Stalingradskoi bitve [Secret tragedy: civil population in the Stalingrad battle]. Volgograd.: Peremena.

Samsonov, A.M. 1989 Stalingradskaia bitva [Stalingrad battle]. $4^{\text {th. }}$ Edition, revised \& enlarged. Moscow: Nauka. 